\title{
Who is dying from Covid-19 in the United Kingdom? A review of cremation authorisations from a single South Wales' crematorium.
}

\author{
Dr Roland Salmon FFPH \\ Dr Stephen Monaghan FFPH \\ Crematorium Medical Referees, \\ Cardiff Thornhill Crematorium \\ Thornhill, \\ CARDIFF CF14 9UA \\ United Kingdom
}

Correspondence to: Dr R. L. Salmon, c/o Bereavement Services, Cardiff Council, Thornhill Cemetry and Cardiff Crematorium, Thornhill Road, CARDIFF CF14 9UA, UK.

email: rolandsalmon@googlemail.com

\begin{abstract}
Background Covid 19 is pandemic in the UK. To date only studies in the UK on hospital deaths have been published in the peer reviewed literature. Legal requirements for cremation in England and Wales require the collection of information that can be used to improve understanding of Covid 19 deaths in both hospital and community settings.

Aim To document demographic and clinical characteristics, including likely place of infection, of individuals dying of Covid 19 to inform public health policy

Design A comprehensive case series of deaths from Covid 19 between 6 April and 30 May.

Setting A crematorium in South Wales

Participants Individuals for whom an application was made for cremation.

Main outcome measures Age, sex, date and place of death, occupation, comorbidities, where infection acquired.

Results Of 752 cremations, 215(28.6\%) were Covid-19 of which 115 (53.5\%) were male and 100 $(46.5 \%)$ female. The median age was 82 years, with the youngest patient being 47 years and the oldest 103 years. Over half the deaths (121/215: 56.3\%) were over 80 years. Males odds of dying in hospital, rather than the community were 1.96 times that of females $(95 \%$ Confidence Intervals (CI) $1.03-3.74, \mathrm{p}=0.054$ ) despite being of similar age and having a similar number of comorbidities. Only $21(9.8 \%)$ of 215 patients had no comorbidities recorded. Patients dying in nursing homes were significantly older than those dying in hospital(median 88y (IQ range 82-93y) $\mathrm{v} 80 \mathrm{y}$ (IQ range 71-87y): $\mathrm{p}<0.0001$ ). Patients dying in hospital had significantly more comorbidities than those dying in nursing homes (median 2: IQ range 1-3 v. 1: IQ range 1-2: $\mathrm{p}<0.001$ ).

Conclusions In a representative series, comprising both hospital and community deaths, persons over 80 with an average 2 comorbidities predominated. Although men and women were represented in similar proportions, men were more likely to die in hospital. Over half the infections were acquired in either hospitals or nursing and residential homes with implications for the management of the pandemic, historically and in the future.
\end{abstract}


medRxiv preprint doi: https://doi.org/10.1101/2020.07.01.20136317; this version posted July 6,2020 . The copyright holder for this preprint (which was not certified by peer review) is the author/funder, who has granted medRxiv a license to display the preprint in perpetuity. It is made available under a CC-BY 4.0 International license .

\section{Background}

Covid-19, a viral infectious disease caused by the SARS CoV 2 virus emerged in China at the end of 2019 and was declared pandemic by the World Health Organisation on 11 March $2020^{1}$. The first case occurred in the UK on 31st January 2020 and in Wales, where 1,441 deaths have occurred as of 12 June $2020^{2}$, on 28th February $2020^{3}$. The disease has given rise to a number of far-reaching public health measures. So far, in the UK, there have been three large community studies, of which in two, the main outcome is deaths in hospital ${ }^{4,5}$ and in the third positive SARS CoV 2 tests $^{6}$. There has also been a small study of risk factors for intensive care unit admissions in South Wales ${ }^{7}$. All identify similar risks for mortality and morbidity; increasing age, male gender, diabetes, chronic heart, lung, kidney or neurological disease, malignancy and dementia. Importantly, although there has been an ecological study comparing death rates, including out-of-hospital deaths, by local authority area, in Great Britain ${ }^{8}$, no UK studies, to date, have reported the characteristics and risks of death in individuals dying from COVID-19 that includes those patients dying out-of-hospital, in nursing and residential homes or at home, as well as those dying in hospital.

In 2012, as a result of The Cremation (England and Wales) Regulations $2008^{9}$, themselves arising out of the Inquiry into Harold Shipman ${ }^{10}$, a new suite of forms for the authorisation of cremation came into use. Although procedures have been temporarily simplified to assist the management of the Covid-19 pandemic $^{11}$, the key information requirements are unchanged. These emphasise that the fact and cause of death has been definitely ascertained and require a brief text account (question 9, form 4) of the "symptoms and other conditions" that led to the conclusions about the cause of deaths. This account, although unstructured, permits a view of the course of the final illness which can be used better to understand deaths from Covid-19.

Cardiff Thornhill Crematorium is a Local Authority run crematorium (run by Cardiff Council, one of 22 unitary local authorities in Wales) that performed 2,850 cremations in 2017, a typical year in terms of activity.

\section{Objectives}

To characterise those individuals dying from Covid-19, that were authorised for cremation, in terms of age, sex, occupation, comorbidities and where the infection had been acquired, in order better to inform public health policy to address the infection.

\section{Methods}

Information was taken from: Cremation Form 4 in which a certifying clinician is required both to record the cause of death (question 11) in a format that reflects the separate Medical Certificate of Cause of Death (MCCD) and to give a brief account (question 9) of the "symptoms and other conditions" that led them to that conclusion: Cremation Form 1 in which the applicant for cremation (usually the next of kin) gives the age and occupation of the deceased. Both forms record the home address, date and time of death. Ethnicity, however, is not recorded.

Deaths were defined as Covid-19 if specifically mentioned in response to q.11 or if a SARS CoV2 positive test was documented in response to q.9. Comorbidities were any relevant conditions mentioned in answer to either of questions 9 or 11.

The authors authorised all patients over the study period. Data was entered onto a structured pro forma; sex, age, occupation, date of death, location of death (hospital, institutional nursing or residential home, own home), comorbidities and whether infection was acquired in hospital (defined as occurring 6 days after admission OR following admission for an unrelated condition). Nursing 
medRxiv preprint doi: https://doi.org/10.1101/2020.07.01.20136317; this version posted July 6, 2020. The copyright holder for this preprint (which was not certified by peer review) is the author/funder, who has granted medRxiv a license to display the preprint in perpetuity. It is made available under a CC-BY 4.0 International license .

and residential home residents were assumed to have acquired their infection in their nursing or residential home unless they fulfilled the criteria for having acquired the infection in hospital.

Analysis was performed in EpiInfo version 7(US Centers for Disease Control and Prevention $(\mathrm{CDC}))^{12}$. Median and interquartile ranges were calculated for age and the number of comorbidities; simple frequencies for other variables. Differences in patient characteristics and comorbidities (i) between men and women and (ii) by place of death were examined using the Mann-Whitney U test for continuous variables and the chi squared test (Yates corrected) for categorical variables.

Patients and the public were not involved in this study, responding, in a timely way, to a Public Health Emergency of International Concern.

\section{Results}

Of the total of 752 cremations authorised over the period of 6th April until 29th May, 215(28.6\%) were Covid-19 of which 115 (53.5\%) were male and 100 (46.5\%) female ( $\mathrm{p}=\mathrm{NS})$. Dates of death are shown in Figure 1. The median age was 82 years, with the youngest patient being 47 years and the oldest 103 years. Over half the deaths (121/215: 56.3\%) were over 80 years. Among 146 patients who died in hospital, 85 (58.2\%) were male and 61 (41.8\%) were female (p NS). Males' odds of dying in hospital, rather than the community were 1.96 times that of females $(95 \%$ Confidence Intervals (CI) $1.03-3.74, \mathrm{p}=0.054$ ) despite being of similar age (males: median age 81y: interquartile (IQ) range $72 \mathrm{y}-87 \mathrm{y} v$ females: $84 \mathrm{y}$ : IQ range $72-90.5 \mathrm{y}$ ) and having a similar number of comorbidities (both sexes: median 2, range $0-7)$. Only $21(9.8 \%)$ of 215 patients had no comorbidities recorded.

Patients' comorbidities, by place of death, are shown in Table 1. Patients dying in nursing homes were significantly older than those dying in hospital(median 88y (IQ range 82-93y) v 80y (IQ range 71-87y): $\mathrm{p}<0.0001$ ). Patients dying in hospital had significantly more comorbidities than those dying in nursing homes (median 2: IQ range 1-3 v. 1: IQ range 1-2: $\mathrm{p}<0.001$ ). Patients dying in hospital were significantly more likely than those dying in nursing homes, to have chronic heart disease $(\mathrm{p}<0.05)$ or chronic pulmonary disease, excluding asthma $(\mathrm{p}<0.05)$ but significantly less likely to have dementia $(\mathrm{p}<0.00005)$. No patient dying in their own home had dementia $(\mathrm{p}<0.001)$.

Of the 31(14\%) patients less than $65 \mathrm{y}, 20$ were recorded as working and occupations included 2 NHS, 2 care sector and 1 transport sector staff.

Of 215 cases of Covid-19, 63 (29.3\%) of infections were hospital acquired and a further 55(25.6\%) acquired in nursing or residential homes.

\section{Discussion and Conclusions}

This is the first comprehensive study of deaths, including individuals dying both in hospital and in the community, in the United Kingdom. Other studies have either looked at patients dying in hospital ${ }^{4,5,7}$ or patients testing positive for SARS CoV 2 in the community ${ }^{6}$ or have been ecological studies $^{8}$.

The study uses the information required by a crematorium, under the law of England and Wales ${ }^{9}$, before a person can be cremated, information which includes a brief clinical account to support the stated causes of death. Although unstructured text, official guidance on completion of the forms does exist ${ }^{13}$ and this information can give a rounded picture of the circumstances leading to a death, similar to a clinical referral letter. Cremation forms, in this way, represent a rich source of 
medRxiv preprint doi: https://doi.org/10.1101/2020.07.01.20136317; this version posted July 6, 2020. The copyright holder for this preprint (which was not certified by peer review) is the author/funder, who has granted medRxiv a license to display the preprint in perpetuity. It is made available under a CC-BY 4.0 International license .

information on the end of life and elements such as the type and appropriateness of care. This timehonoured and legally laid down process, can thus be used to promote health and prevent disease. To utilise better, this would require a degree of central organisation at regional or national level. The introduction of the Medical Examiner system, in England and Wales ${ }^{14}$ may present an opportunity to do this but hitherto the focus has been almost entirely on patient satisfaction (or, more strictly, that of their relatives) and healthcare quality. Whilst important, this ignores the usages that mortality statistics have been put to, historically, to tackle other areas of public health such as health protection and health promotion, such as Clean Air Acts, following the 1953 London smog or the current tracking of Covid-19. In fact, better collation of mortality statistics and more extensive and systematic recording of clinical, pathological and risk factor data and linking those mortality statistics with other public data sources (eg cancer registries, prescribing data, hospital episode statistics, air quality data) would allow the contemporary quantification of several "big ticket" current public health issues, other than Covid-19, such as, alcohol use, obesity, anti-microbial resistance and air pollution.

The denominator population, from which patients that use Cardiff Thornhill crematorium are drawn, is difficult to characterise exactly, as more than one crematorium serves the Cardiff Council area and equally cremations are accepted from other local authority areas. Cardiff itself has a population of 335,145 persons, according to the 2011 census and Thornhill crematorium users are thought broadly to reflect this.

Deaths occurred, as in other studies, worldwide, mainly in the elderly (median age 82y) with over half in those over 80 years old and with over $90 \%$ having pre-existing medical conditions. The proportion of men and women in the whole group did not differ significantly, unlike the other UK studies, restricted to deaths in hospital. However, an excess of male deaths, in the subset of deaths occurring in hospital, was similar to these other UK studies. The odds of men dying in hospital was thus nearly twice that of women, even though they were of similar age with a similar number of comorbidities. This phenomenon is unexplained and it will be of interest to know if it is replicated in other settings where deaths in the community are also recorded.

Over half the infections, plausibly, were acquired in institutional care settings, of which nearly $30 \%$ were acquired in hospital. Concerns have been raised about hospital transmission in other UK settings but in the absence of official figures, the proportion has been estimated as $5-20 \%{ }^{15}$. This inevitably poses the question of what proportion of these could have been prevented by more effective infection control procedures. It is particularly sobering to compare these percentages with the purported benefits of Non-Pharmaceutical Interventions (NPIs), as modelled by Imperial College, London, ${ }^{16}$ which were so influential in guiding UK government policy at the start of the pandemic. The biggest predicted percentage reduction in deaths, for any of the combinations of NPIs was also $50 \%$. The implication of this is that more focussed interventions to prevent the introduction of SARS CoV 2 and to control its spread, in healthcare settings, may have had the same potential to reduce deaths as the general social distancing and other costly measures that were, in the event, introduced. It poses the question whether the UK's high mortality, when compared with other European countries ${ }^{17}$, has as much to do with its historically high hospital occupancy rates $^{18}$ and underfunding of the social care sector ${ }^{19}$ as it does with the, widely blamed, delay in introducing lockdown ${ }^{20}$. Indeed, given the apparent ineffectiveness of the NPIs in keeping mortality down, a focus on control of SARS CoV 2 infection in hospitals, nursing and residential homes might have been a more effective approach in limiting deaths and certainly would not have resulted in the same social and economic disruption as lockdown and general social distancing. Going forward, this may still represent the most effective use of testing and tracing teams rather than attempting to extinguish spread in a wider community of people who would, largely, be expected to recover from the infection without mishap. 
medRxiv preprint doi: https://doi.org/10.1101/2020.07.01.20136317; this version posted July 6,2020 . The copyright holder for this preprint (which was not certified by peer review) is the author/funder, who has granted medRxiv a license to display the preprint in perpetuity. It is made available under a CC-BY 4.0 International license .

\section{Conclusion}

Cremation certificates represent a useful source of information on health problems locally and could, with greater co-ordination, contribute to a national picture. In a representative series of deaths, in persons, authorised for cremation, in South Wales, comprising both hospital and community deaths, persons over 80 with an average 2 comorbidities predominated. Although, unlike most other studies, there were similar proportions of men and women overall, men were more likely to die in hospital. Over half the infections were acquired in either hospitals or nursing and residential homes with implications for the management of the pandemic, historically and in the future.

\section{Acknowledgements}

Bereavement Services staff, Cardiff Council.

Sian King, Evidence Service, Public Health Wales, Swansea

\section{Data sharing}

The data set would, ordinarily, be shared on application to the authors.

\section{Conflict of Interest}

Dr Salmon and Dr Monaghan are Crematorium Medical Referees for the Cardiff Council Crematorium, Thornhill, Cardiff and are remunerated on a fee for service basis.

\section{Funding}

No dedicated funding has been obtained for this work

\section{Transparency Statement}

Dr Salmon, the lead author (the manuscript's guarantor) affirms that the manuscript is an honest, accurate, and transparent account of the study being reported; that no important aspects of the study have been omitted; and that any discrepancies from the study as planned (and, if relevant, registered) have been explained.

\section{Ethical approval}

This study uses information required under the Cremation (England and Wales) Regulations 2008, which may be used for the purposes of the public interest.

\section{Contributions}

Dr Salmon conceived the study, collected and analysed the data and edited the text. Dr Monaghan advised on study design, collected data and edited the text. 
medRxiv preprint doi: https://doi.org/10.1101/2020.07.01.20136317; this version posted July 6,2020 . The copyright holder for this preprint (which was not certified by peer review) is the author/funder, who has granted medRxiv a license to display the preprint in perpetuity. It is made available under a CC-BY 4.0 International license .

\section{References}

1. WHO. WHO Coronavirus disease 2019 (COVID-19). Situation report 51. 11 March 2020 https://www.who.int/docs/default-source/coronaviruse/situation-reports/20200311-sitrep-51covid-19.pdf?sfvrsn=1ba62e57 10

2. Public Health Wales. Coronavirus (Covid-19) https://phw.nhs.wales/topics/latestinformation-on-novel-coronavirus-covid-19/ accessed 13 June 2020

3. BBC News.Coronavirus: First Welsh case among three new UK diagnoses. https://www.bbc.co.uk/news/uk-51673068 accessed 13 June 2020

4. Williamson ES et al. OpenSAFELY: factors associated with COVID-19-related hospital deaths in the linked electronic health records of 17 million adult NHS pateints. MedXRiv preprint doi: https://doi.org/10.1101/2020.05.06.20092999 this version posted May 7, 2020.

5. Docherty AB et al. Features of 20,133 patients in hospital with covid-19 using the ISARIC WHO Clinical Characteristics Protocol:prospective observational cohort study. BMJ 2020;369m1985|doi:10.1136/bmj.m1985

6. de Lusignan S et al. Risk factors for SARS-CoV-2 among patients in the Oxford Royal College of General Practitioners Research and Surveillance Centre primary care network: a cross sectional study. Lancet 2020.https://doi.org/10.1016/S1473-3099(20)30371-6.

7. Baumer T, Phillips E, Dhadda A, Szakmany S. Insights into the epidemiology, of the first wave of COVID-19 admissions in South Wales - the interplay between ethnicity and deprivation. Basel: MDPI AG; 2020: doi:10.20944/preprints202006.0029.v1

8. Leighton SP, Leighton DJ, Herron J et al. Risk factors for COVID-19 related in-hospital and community deaths by local authority district in Great Britain. MedXRiv preprint doi:https://doi.org/10.1101/2020.05.21.20108936 this version posted May 232020

9. Ministry of Justice. The Cremation (England and Wales) Regulations 2008. UK StatutoryInstruments2008.No.2841 http://www.legislation.gov.uk/uksi/2008/2841/contents/made

10. Smith J. Shipman the final report. 2005. webarchives.nationalarchives.gov.uk/20090809045112

11. Luce T. Covid 19: Death certification in England and Wales. BMJ 2020;369: m1571 https://www.bmj.com/content/369/bmj.m1571

12. US Centers for Disease Control and Prevention (CDC). Epi Info ${ }^{\mathrm{TM}} 7$ User Guide v3. Atlanta. CDC. March 212016

13. Ministry of Justice. The Cremation (England and Wales) Regulations 2008. Guidance to medical practitioners completing forms Cremation 4 and 5 amended. London. Ministry of Justice. April 62018 amended October 12019.

14. Fletcher A, Coster J, Goodacre S. Impact of the new medical examiner role on patient safety.BMJ2018;363:k5166 doi: 10.1136/bmj.k5166 (Published 14 December 2018)

15. Iacobucci G. Doctors sound alarm over transmission in wards. BMJ 2020;369m2013 published May 23

16. Ferguson NM et al. Impact of non-pharmaceutical interventions (NPIs to reduce COVID-19 mortality and healthcare demand. London. March 16 2020. Imperial College:DOI: https://doi.org/10.25561/77482

17. Statens Serum Institut. EuroMOMO: European mortality monitoring activity. https://www.euromomo.eu/

18. Alderwick H, Ham C. Sustainability and transformation plans for the NHS in England: what do they say and what happens next? BMJ 2017;356:doi: http s://doi.org/10.1136/bmj.j1541

19. Oliver D. Social care—-back to an uncertain future $B M J 2020 ; 368$ doi:https://doi.org/10.1136/bmj.m761

20. Scally G, Jacobson B, Abbasi K. The UK's public health response to covid-19 BMJ 2020; 369 doi: https://doi.org/10.1136/bmj.m1932 
medRxiv preprint doi: https://doi.org/10.1101/2020.07.01.20136317; this version posted July 6, 2020. The copyright holder for this preprint (which was not certified by peer review) is the author/funder, who has granted medRxiv a license to display the preprint in perpetuity. It is made available under a CC-BY 4.0 International license .

Table 1. Characteristics and comorbidities in patients dying of Covid-19, by place of death

\begin{tabular}{|c|c|c|c|c|}
\hline $\begin{array}{l}\text { Characteristic, } \\
\text { Comorbidities }\end{array}$ & Hospital & $\begin{array}{c}\text { Nursing or } \\
\text { Residential Home }\end{array}$ & Own home & All \\
\hline Study subjects & 146 & 43 & 10 & 215 \\
\hline $\begin{array}{c}\text { Age }\left(y, \begin{array}{c}\text { median, } \\
\text { range })\end{array}\right. \\
\text { IQ }\end{array}$ & $80(71-87)$ & $88(82-93)$ & $75(68-91)$ & $82(72-89)$ \\
\hline \multicolumn{5}{|l|}{ Age Range } \\
\hline $40-49 y$ & $1(0.7 \%)$ & 0 & $1(10 \%)$ & $2(0.9 \%)$ \\
\hline $50-59 y$ & $7(4.8 \%)$ & 0 & $1(10 \%)$ & $10(4.6 \%)$ \\
\hline $60-69 y$ & $24(16.4 \%)$ & $3(7.0 \%)$ & $1(10 \%)$ & $31(14.4 \%)$ \\
\hline 70-79y & $38(26.0 \%)$ & $5(11.6 \%)$ & $3(30 \%)$ & $51(23.7 \%)$ \\
\hline 80 plus y & $76(52.1 \%)$ & $35(81.4 \%)$ & $4(40 \%)$ & $121(56.3 \%$ \\
\hline $\begin{array}{c}\text { Comorbidities (median, IQ } \\
\text { range) }\end{array}$ & $2(1-3)$ & $1(1-2)$ & $1(1-3)$ & $2(1-3)$ \\
\hline Any comorbidity & $135(92.5 \%)$ & $35(81.4 \%)$ & $8(80 \%)$ & $194(90.2 \%)$ \\
\hline Chronic heart disease* & $42(28.8 \%)$ & $5(11.6 \%)$ & $2(20 \%)$ & $37(17.2 \%)$ \\
\hline $\begin{array}{l}\text { Chronic pulmonary disease } \\
\text { except Asthma* }\end{array}$ & $33(22.6 \%)$ & $3(7 \%)$ & $1(10 \%)$ & $41(19.1 \%)$ \\
\hline Asthma & $7(4.8 \%)$ & $2(4.7 \%)$ & 0 & $9(4.2 \%)$ \\
\hline Chronic kidney disease & $14(9.6 \%)$ & $2(4.7 \%)$ & $1(10 \%)$ & $20(9.3 \%)$ \\
\hline Diabetes mellitus & $25(17.1 \%)$ & $6(14.0 \%$ & $2(20 \%)$ & $37(17.2 \%)$ \\
\hline Stroke & $24(16.4 \%)$ & $6(14.0 \%)$ & $1(10 \%)$ & $31(14.4 \%)$ \\
\hline Dementia $*+$ & $36(24.7 \%)$ & $28(65.1 \%$ & 0 & $66(30.1 \%)$ \\
\hline Cancer & $25(17.1 \%)$ & $2(4.7 \%)$ & $3(30 \%)$ & $34(15.8 \%)$ \\
\hline Myeloproliferative Disorders & $7(4.8 \%)$ & $1(2.3 \%)$ & 0 & $9(4.2 \%)$ \\
\hline Liver disease & $5(3.4 \%)$ & 0 & 0 & $5(2.3 \%)$ \\
\hline Rheumatological Disorders & $7(4.8 \%)$ & 0 & $1(10 \%)$ & $11(5.1 \%)$ \\
\hline Hypertension & $26(17.8 \%)$ & $2(4.6 \%)$ & $1(10 \%)$ & $30(14.0 \%)$ \\
\hline
\end{tabular}

*: difference between hospitals and nursing or residential homes, significant at $\mathbf{p}<0.05$ or less $+:$ difference between nursing or residential home and own home, significant at $p<0.001$ 
medRxiv preprint doi: https://doi.org/10.1101/2020.07.01.20136317; this version posted July 6, 2020. The copyright holder for this preprint (which was not certified by peer review) is the author/funder, who has granted medRxiv a license to display the preprint in perpetuity. It is made available under a CC-BY 4.0 International license.

\section{Figure 1}

\section{Epidemic Curve: Deaths from Covid 19}

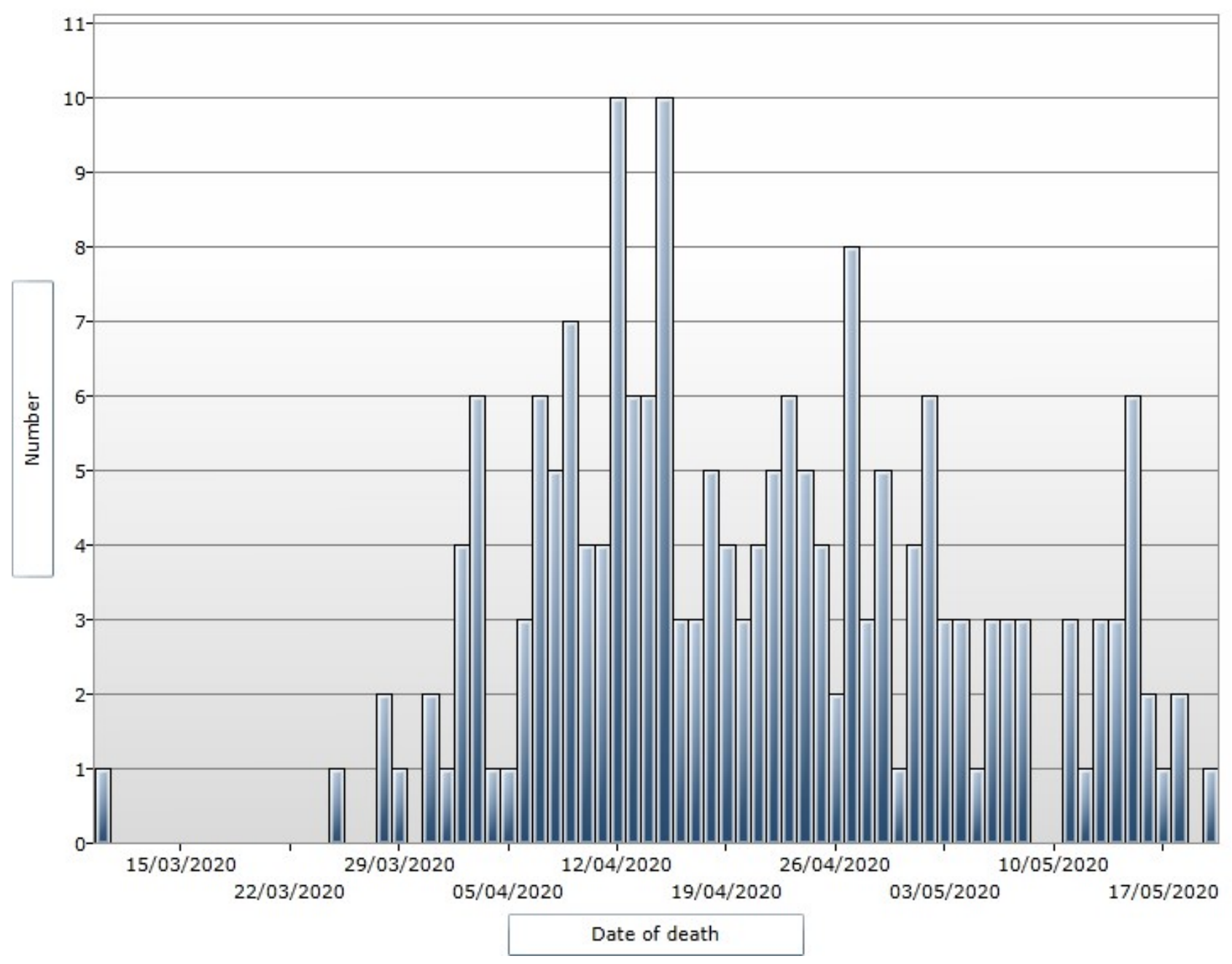


medRxiv preprint doi: https://doi.org/10.1101/2020.07.01.20136317; this version posted July 6,2020 . The copyright holder for this preprint (which was not certified by peer review) is the author/funder, who has granted medRxiv a license to display the preprint in perpetuity. It is made available under a CC-BY 4.0 International license .

\section{Appendix 1}

STROBE Statement - checklist

\begin{tabular}{|c|c|c|}
\hline & Item No. & Where found (page) \\
\hline Title and abstract & 1 & 1,2 \\
\hline \multicolumn{3}{|l|}{ Introduction } \\
\hline Background/Rationale & 2 & 2,3 \\
\hline Objectives & 3 & 3 \\
\hline \multicolumn{3}{|l|}{ Methods } \\
\hline Study design & 4 & 3 \\
\hline Setting & 5 & 3 \\
\hline Participants & 6 & 3 \\
\hline Variables & 7 & 3 \\
\hline Data sources/measurement & 8 & 3 \\
\hline Bias & 9 & 3 \\
\hline Study size & 10 & 3 \\
\hline Quantitative variables & 11 & 3 \\
\hline Statistical methods & 12 & 3 \\
\hline \multicolumn{3}{|l|}{ Results } \\
\hline Participants & 13 & 3 \\
\hline Descriptive data & 14 & 3,4, Table 1, Figure 1 \\
\hline Outcome data & 15 & 3,4, Table 1 \\
\hline Main results & 16 & 3,4, Table 1 \\
\hline Other analyses & 17 & None \\
\hline \multicolumn{3}{|l|}{\begin{tabular}{|l|} 
Discussion \\
\end{tabular}} \\
\hline Key results & 18 & 4,5 \\
\hline Limitations & 19 & 4,5 \\
\hline Interpretation & 20 & 4,5 \\
\hline Generalisability & 21 & 4,5 \\
\hline \multicolumn{3}{|l|}{ Other information } \\
\hline Funding & 22 & 6 \\
\hline
\end{tabular}

